\title{
The Process and Value of Self-Study in a Medium-sized University Library
}

William L. Beck and Marsha L. Nolf

\begin{abstract}
This paper reports the steps taken to implement, personalize, develop, use, and evaluate a self-study process which follows a set of academic library standards suggested by Antoinette M. Kania. Included are organization and meeting strategies to determine and implement performance measures, qualitative and quantitative measures of the process, and specific recommendations. Ongoing results include improved communication, more effective strategic planning, the establishment of meaningful policies and procedures, and better use of library assets and services, all of which benefit the library employees as well as the patrons and university.
\end{abstract}

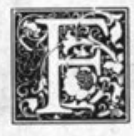

uture historians, looking back at higher education in the 1990 s, may well call this the Age of Reports. What with program reviews; accreditation reviews; short-range and long-range planning documents; needs assessments; outcomes assessments; user surveys; needs surveys; automation projections; personnel analyses; national and professional compliance reports; accountability studies, etc., librarians (and everyone else in the academic world) complain that so much of their time is devoted to writing reports that they neglect the professional duties they are reporting. Besides, who in authority ever reads these reports, or, having read them, bothers to act upon them?

So, when the library staff of the Louis L. Manderino Library of California University of Pennsylvania heard in September 1987 that we were required by the State System of Higher Education's [SSHE] Board of Governors to conduct an exhaustive self-study (program review), our response was cynical. Was this really necessary? Would our report be read?
What good would it do for our library? We already knew we were doing a "great job" because of recent increases in circulation, positive responses from users, and major tangible improvements.

As if the SSHE requirement weren't enough, we knew that similar self-analytical reports would soon be required by two other accrediting agencies: the Middle States Association of Colleges and Schools and the National Council for the Accreditation of Teacher Education. Not one report, but three. We accepted the challenge and, in the end, killed the three birds with one stone. The long, eighteenmonth self-study process and ensuing final report provided much of the Manderino Library's portion of the required university report to each accrediting agency.

In this article, we describe what has happened to the Manderino Library staff since that challenge. The self-study program we have produced is more than just a survey, more than a summary full of charts and tables. It is full of the thoughts and contributions of each

William L. Beck is Dean of Library Services and Marsha L. Nolf is Public Services Coordinator and Bibliographic Instruction Librarian at the Louis L. Manderino Library, California University of Pennsylvania, California, Pennsylvania 15419. 
member of our library family. This comprehensive, introspective accumulation of all aspects of library operations cannot help but tell the truth about what we do and what we should be doing. We've already gone far beyond our original "assignments" and have used our findings to reorganize major and minor aspects of operations. We now have a structure that functions as a skeleton, as a customized model, as a check-and-balance system, and as a standard of comparison. Our method of self-study proved the value of using an excellently researched outline while allowing ourselves creative modifications as we recognized the need for them. Convinced that such a review can benefit the working organization of a medium-sized academic library, we want to share our experience so that others can use what might benefit them.

\section{THE UNIVERSITY AND ITS LIBRARY}

A few words about our university and library and the mandate for the study will help illustrate our starting point. California University of Pennsylvania (CUP) is a public, regional, state university in southwestern Pennsylvania, one of fourteen institutions that comprise Pennsylvania's State System of Higher Education. Theschool, nestled in the Monongahela River Valley, where steel, coal, and coke once ruled, has an enrollment of 6,748 students, with 290 faculty in the Colleges of Education and Human Services, Liberal Arts, Science and Technology, and the School of Graduate Studies and Research.

The chief mission of our mediumsized academic library is to support the curricular offerings of CUP and to provide services related to reference, interlibrary loan, online searching, and bibliographic instruction for students and faculty. As a vital part of the area's transition from heavy industry to scientific research and technology, our library is housed comfortably in a twelve-yearold building that accommodates a collection of 310,000 volumes, 1,700 periodical subscriptions, 63,000 audiovisual materials, and over 1.2 million microforms.

The Manderino Library is the largest library among those serving the univer- sities in the State System of Higher Education. The library is a selective depository for Pennsylvania state documents and, since 1986, U.S. government documents. Circulation figures exceed 152,834 items per year, with the library being an interlibrary loan net lender by a factor of four to one. Our online catalog, using TEXTRIEVE software, is tied to an in-house online circulation system. We currently subscribe to nine indexes on CD-ROM.

The staff consists of a dean of library services, a systems analyst (at management level), ten professional librarians, fifteen clerical assistants, six full time equivalent graduate assistants, and eighty to one hundred student assistants. The 1990 budget was $\$ 1.7$ million, with one-third of that allocated for materials and operating expenditures. Further, with unionized nine-month and twelve-month employees on staff, we must operate with due consideration to collective bargaining requirements and constraints. Having covered the what, why, and who of our story, we will now tell you how we did our self-study.

\section{OUR "ASSIGNMENT" FROM SSHE}

"Criteria for Review of Support Programs. Universities should develop separate criteria for review of academic and student support programs. Such reviews should include some sort of qualitative feedback from users of the services provided by the program, cost-benefit data, and assessment of the unit's effectiveness in working with other areas of the university."1

Fortunately, two months after we received this assignment, the dean of library services and a librarian attended a workshop about self-study in academic libraries. They returned from Rutgers University with Antoinette Kania's excellent and appropriate model for "[encompassing] qualitative standards for accreditation purposes and [suggesting] quantitative performance measures for local self-evaluation purposes."

\section{SELF-STUDY BEGINS}

In January 1988, all Manderino Library employees received copies of rele- 
vant materials and Kania's process. At two subsequent meetings, we explained the rationale and benefits of using Kania's structure to analyze what we do and how well we do it. We carefully emphasized that all library employees would share all the tasks of effecting change where necessary and that, ultimately, all of us would benefit. During open discussion, we determined that most were willing to give Kania's model, a model that had not yet been applied, a try. This need for open and complete communication is vital for any self-study effort.

Our library administrator knows his staff and is accustomed to dealing with them effectively within the confines of two separate collective bargaining agreements. Anticipating employees' fears, he carefully planned each innocent detail to minimize internal worries and to establish the prevailing group harmony. The result: about 80 percent of librarians and staff bought the concept during the initial planning stages.

\section{This need for open and complete communication is vital for any self-study effort.}

The dean also took care to balance membership of committees. He worked very hard to select people who were complementary in temperament, work ethic, abilities, and qualifications, while mixing new employees with veterans and extroverts with introverts. He talked with each employee separately about selfstudy, then spent several more weeks imagining worst-case scenarios and how to circumvent them.

At the third meeting, we formalized our structure. The entire staff was divided into four groups, each representing a mix of faculty and staff, public services and technical services, as explained in the paragraph above. Meeting separately, each group selected its leader and recorder, then listed and discussed the library's strengths, weaknesses, and problems. One hour later, the entire group reassembled, and each of the four recorders presented a report orally and on a blackboard. Then, the dean of library services offered his perceptions, and they were added to the board.

The overall viewpoint that emerged was the same as each group had determined separately. We were amazed to see that everyone had identified the same problems and situations. We already felt united and eager to go on with the self-study. The summarized reports of each group were typed and distributed to the entire staff. We cannot emphasize too strongly that the following points are crucial when this process is being undertaken in a collective bargaining environment:

1. All staff must be involved.

2. Recommendations must be implemented in an equal manner throughout the entire library system (i.e., not selectively).

3. Once the self-study process is completed, the report and strategic plan must be implemented, not shelved and ignored.

4. No one is to feel threatened in this process of examining everything. Communicate clearly that this process is not a cover-up for a secret agenda to eliminate or downgrade positions.

\section{A STEERING COMMITTEE IS FORMED}

Shortly thereafter, the dean appointed a steering committee consisting of three librarians, two support staff, a graduate student, and an undergraduate student. ${ }^{3}$ Most of the committee members had been leaders or recorders in the joint meeting. The chairman was a bibliographic instruction librarian who had worked at Manderino Library for only one year. Among other qualities, she could contribute a fresh outlook and thirteen years as a head cataloger elsewhere. She was prepared to guide the self-study process with attention to both public and technical services viewpoints. Moreover, she was known for her exceptional organizational, interpersonal, and communications skillswhich would result in a reliablemanagement style to guide the self-study process.

The dean charged the Self-Study Steering Committee (SSC) to structure a 
process that would address the library's weaknesses and problems, assess the strengths, and develop a framework so that the study could involve all the staff. Almost immediately, the SSC decided to use Kania's model as our model for selfstudy. ${ }^{4}$ The SSC met weekly during the spring semester in 1988.

Each SSC member researched one division of Kania's five-point outline: goals and objectives standards; collection standards; access/use standards; staff standards; and administration standards. Guided by Kania's standards and assuming the role of "investigative reporter," each SSC member asked and reasked questions until, as a group, we had talked to every person on the library staff. This method of cross-checking, examining, and confirming facts revealed some interesting things about current operations and library history. We learned that although our library excelled in many areas, we needed to examine some areas more closely and perhaps change them.

\section{No one is to feel threatened in this process of examining everything.... This process is not a cover-up for a secret agenda to eliminate or downgrade positions.}

Here is an example of how SSC members operated. Kania's outline includes the following collection standard: "While the institution should support its own essentially self-contained library, cooperative relationships with other libraries and agencies may also be developed to supplement the library's own resources." ${ }^{5}$ The SSC member responsible for this area interviewed the interlibrary loan librarian and the public services coordinator. Supported by extensive documentation, the SSC member noted that our library participates in three major types of cooperative arrangements: interlibrary loan, reciprocal borrowing, and consortia efforts. This SSC member uncovered another example of resource sharing, the recent edition of
Access Pennsylvania on CD-ROM. It was easy to determine that we fulfilled this standard.

A second SSC member investigated administration standards such as this one: "The library administrator(s) must have the appropriate authority and responsibility for the development and management of the library as well as the opportunity to participate in campuswide planning and governance." 6 This was also easy to confirm after the SSC member interviewed the dean of library services and reviewed his job description and numerous extracurricular activities on campus.

Although committee members gathered their preliminary information within two months, complex library work schedules complicated the availability of common meeting times. To keep the project moving within the time constraints, the SSC made a preliminary report at the close of the spring semester. In a memorandum to the dean of library services, it recommended that Manderino Library use Kania's model as a basis for self-study, and that fourteen activities related to topics in that model be studied further by (new) subcommittees and individuals.

\section{THE SSC MAKES FOURTEEN RECOMMENDATIONS}

Among the fourteen recommendations, the SSC gave precedence to the standards we did not then fulfill. The use of italics and emphasis upon the verbs must, should, and may correspond to Kania's outline. ${ }^{7}$

1. "The library must develop and communicate goals and objectives for its own program that are compatible with those of the institution." The library's general mission statement must be updated and rewritten in harmony with the newly revised university mission statement. A new library committee should be formed for this purpose.

2. "The development and review of the [aforementioned] goals and objectives should be conducted by the library staff working in concert with the administration, faculty, 
and students." ${ }^{19}$ After the new library mission statement is written and adopted, each department within the library should determine and write goals and objectives and decide how to achieve them. Annual review of these goals and objectives will help ascertain their status and value.

3. A "collection standards committee" must be formed, and it must immediately address the following standard: "The library collection must support the instructional program of the institution. ${ }^{10}$ First, this committee must choose an appropriate measurement tool for evaluating and improving the vitality of our collection. Also, the collections standards committee should develop a means for increasing faculty involvement in the book and periodical selection process; reestablish a "representative faculty advisory committee"; and review/revise our materials-weeding policy.

4. The library should form a standing "advisory automation committee" to assist the systems analyst in planning for ongoing technological innovations in automated systems within the library. "The Public and Technical Services Departments should be adequately represented and should have input in determining goals and objectives for providing adequate, consistent, and integrated bibliographic access to audiovisual equipment, maps, pamphlets, the Special Collections Room, periodicals, archival materials, realia, and loose-leaf publications such as the Readers Advisory Service. This committee should disseminate information to the entire library staff, and when appropriate, suggest training and continuing education opportunities for the staff.

5. The library must form an ad hoc "serials committee" to study and analyze the library's current treatment of serial publications. ${ }^{12}$ First, the committee should define this library's use of the term serials, then they may develop a flow chart of all aspects of serials procedures (acquisitions, cataloging, circulation, binding, etc.). Further, they should consider this library's need for a serials cataloger or librarian.

6. The Technical Services Department should develop a statement setting a time limit on items awaiting cataloging and classification. ${ }^{13}$

7. The Reference Department should develop a valid tool to determine whether the library is providing patrons with adequate assistance and accurate information. Currently, the Reference Department has quantitative data but no method to assess the quality of services. They should compare notes with the "library user survey committee" to avoid duplicating efforts. ${ }^{14}$

8. The library should form an ad hoc "media services committee." First, this committee should define the role of "media services" in our library, then assess how adequately our equipment serves faculty and students in their course-related work. The media services committee should also determine how well our audiovisual collection supports the instructional program of the university. ${ }^{15}$

This committee may consider this guideline from Kania: "Depending on the organizational structure of the institution, the library may develop services other than those associated with traditional library functions, i.e., instructional materials, learning laboratories, etc."16 This committee may wish to develop a flowchart of all aspects of media services procedures (from acquisitions to cataloging to circulation of audiovisual materials and equipment) for visual clarification and consolidation. Finally, this committee may also review Media Services' personnel needs.

9. The bibliographic instruction librarian should provide voluntary, in-service training for the library staff (such as library orientation for new employees). ${ }^{17}$ 
10. The library should form an ad hoc "library user survey committee." Extensive student and faculty surveys were conducted in 1979 and 1983; another campuswide poll of faculty and students would serve us well now. The ad hoc committee should begin to compile survey questions, determine how to distribute the survey, and be prepared to conduct it and study the results in the 1988 fall semester. The survey should focus on, but not be limited to: library hours, reference desk hours, analysis of library users, awareness and use of library services, and the types of services the library should provide. ${ }^{18}$

11. An ad hoc "communication committee" should be formed to encourage the improvement of library communication (in-house and campuswide). At the very first selfstudy meeting (with the entire staff), all agreed that lack of communication is a weakness that can undermine everyone's hard work. Good communication is a must for effective operations and cooperation among us.

However, effective ongoing communication among individuals and groups can be difficult to achieve. Thus a most important task for this committee is to determine how to keep the channels open and working in everyone's mind. Already, many suggestions have been made. We must tell each other what we need to know, or our overall progress will be thwarted. ${ }^{19}$

12. An ad hoc "in-service training committee" should be formed to identify educational sources and programs of possible use and relevance to library staff members. However extensive our formal education, we all want to keep up to date with new information and technological innovations, and to know more about intralibrary operations. This committee would look at voluntary, inservice training both internally and externally. Teaching each other and learning together will help us become stronger, equal members of a team. ${ }^{20}$

13. The dean of library services must revise the library organization chart and communicate any revisions to the entire library staff. Perhaps an ad hoc committee (with adequate representation from the Public and Technical Services Departments) could be formed to assist the dean. ${ }^{21}$

14. The dean of library services may want to investigate the creation of a position of assistant to the dean of library services. The SSC came to this conclusion after interviewing the dean for over twenty hours about library policies, procedures, and history.

We were pleased to note that Manderino Library excelled in many of Kania's standards. However, we noted with some bemusement that we excelled primarily in the standards labelled should and may. Now that we could look at our overall performance objectively, we suddenly saw it in black and white: we were conscientiously doing most of the shoulds and all of the mays. We had unintentionally neglected many of the musts.

As for the needs-to-improve list, the dean agreed with the SSC's fourteen recommendations. Immediately, he and the SSC chair appointed nine specialized subcommittees to study specific topics and recommendations. The subcommittee titles are:

- The Goals and Objectives Subcommittee

- The Collection Standards Subcommittee

- The Automation Subcommittee

- The Serials Subcommittee

- The Media Services Subcommittee

- The User Survey Subcommittee

- The Communication Subcommittee

- The In-Service Training Subcommittee

- The Organization Chart Subcommittee

In addition, the public and technical services coordinators, bibliographic instruction librarian, and the dean of library services agreed to study the recommendations directed to them.

All of these subcommittees worked independently of the SSC and the dean of library services. To enforce our commit- 
ment to communication among ourselves, though, all subcommittees distributed copies of their minutes from meetings to the SSC chairman, the dean, and the staff lounge bulletin board. The subcommittees frequently sought advice or clarification of points from the SSC, and when requested, theSSC chairman attended a subcommittee meeting. When necessary, the dean prodded slow-moving subcommittees and individuals. Here are two examples of what happened when subcommittees' discussions were acted upon.

The results of the first example were most typical. The work of the Goals and Objectives Subcommittee led to fruitful action and the successful completion of decisions and plans. At the beginning of the self-study process, Manderino Library did not fulfill Kania's first standard to "develop and communicate goals and objectives for its own program that are compatible with those of the institution." The SSC determined that Manderino Library's previous written general mission statement was in need of revision, and this subcommittee rewrote it as follows:

The mission of the Louis L. Manderino Library is to support the goals and objectives of California University of Pennsylvania through effective organization of materials and technological resources. The Library's role is to provide resources, instruction, and services to meet the educational, recreational, and research needs of faculty, students, alumni, and community patrons within the region.

This subcommittee also generated a list of six goals for Manderino Library. All were communicated to and approved by the entire library staff. The second example, fortunately, was one of a kind. The newly established In-Service Training Subcommittee had used a formal questionnaire to survey the wants and needs of all library staff members, especially concerning established and new uses for automated systems and related innovations. Replies reaffirmed that the majority did want ongoing programs for internal orientation and training as well as outside speakers to expand their horizons.
The In-Service Subcommittee developed these ideas and suggested other means of continuing education in the hope of creating a sense of unity of purpose and continued amiability among all library employees. In early 1989 and 1990, they sponsored two programs on stress management, a first-aid workshop, a presentation by the university's grants director, and a slide show about Malawi, Africa.

Unfortunately, enthusiasm ebbed quickly. Would-be participants dropped out, and several programs were poorly attended or canceled. Informal surveys indicated that perhaps the appeal of these voluntary continuing education sessions was not equal to the energy and time required or the disruption of established personal rituals, such as family plans. What had sounded interesting in discussion and on paper was ultimately rejected.

At this point, it should be evident to the reader that we took Kania's model and applied it to our own institution, making minor modifications as the need for them arose. It worked for us. We omitted none of Kania's points because we believed that all were necessary to comply with the various sets of requirements in outside evaluations we had to satisfy.

Moreover, we added weeks of cautionary planning to maximize the effectiveness of Kania's outline, and we added two conditions (musts) of our own: communication and training. In retrospect, we can see how essential communication was and still is. Fortunately, we had perceived that the process would not work unless we added crucial communication before and during all steps. Even as communication became excessive-and people complained of reading minutes-they worried if they missed something. We grew weary of telling everyone everything, yet found it addicting and beneficial. So many sets of different meeting minutes appeared on the staff bulletin board that other notices would not fit. Everyone was typing, making photocopies, and stuffing mailboxes. Eleven groups of people were producing and distributing different sets of minutes regularly. 
Still, all that paper didn't mean that peopleactually read everything. Like most organizations, we suffered from the universal problem of getting people to read things. Oddly enough, during the selfstudy this problem almost disappeared. People were personally involved enough to stay curious about new developments as time went on. Peer pressure may have helped as well. Individuals could no longer use the excuse "I didn't know" because open, consistent, and overwhelming communiques appeared everywhere, and everyone knew it.

\section{FINISHING TOUCHES}

After all subcommittees and individuals had submitted their final reports to the SSC, the SSC chair wrote a 300-page progress report (with the necessary assistance of a word processor and a secretary). This progress report would later be reviewed by our external and internal consultants, whom the SSC chose during the fall 1988 semester. Agreeing to be our external consultant was the person whose research and selfstudy model had provided so much of our structure: Antoinette Kania. Our unanimous choice for internal consultant was JoAnn Nelson, a full professor in the Educational Studies Department at CUP, who also holds an M.L.S.

The self-study process forced us to conduct studies and surveys to analyze our performance, services, and interactions with clients.

Prior to spending two days in Manderino Library during the spring semester of 1989, each consultant had read the SSC's 300-page progress report. Both consultants' written reports were included as appendices in the final SSC report, which, at their suggestion, was greatly condensed to sixty-one pages. Both Kania and Nelson reaffirmed Manderino Library's many strengths and three major weaknesses (collection development, serials, and media services) that had already been identified by the SSC. We were pleased that the consultants found our self-study to be so productive and so precisely on target.

In her external consultation report, Kania suggested that we undertake a "review of the library's strategic plan in the light of [departmental objectives]." The dean agreed and asked that the SSC reconvene at the close of the self-study process to review the library's five-year strategic plan. Weary of months of selfexamination, members of the SSC were not immediately receptive to this idea. In short, we did not wish to embrace the new burdens of strategic planning.

To help us rejuvenate and refocus ourselves, the dean suggested that we look at a book by Donald E. Riggs. In Strategic Planning for Library Managers, Riggs summarized where we had been and where we were now:

Strategic planning begins with an objective analysis of the library's current strengths and weaknesses and how these weaknesses can be corrected. The appraisal must cover every functional area of the library. The results of this self-analysis can then provide a base for pursuing the strategic planning process. ${ }^{22}$

Back on track, the Self-Study Steering Committee found, to our surprise, that producing a new five-year strategic plan for the library was relatively effortless because of the logic and completeness of our self-study review. Quickly finishing this new task, the SSC recommended that the following objectives be included in the dean's next revision of Manderino Library's strategic plan. With his approval, the SSC further suggested that the appropriate library department, committee, or individuals provide activities, budget requirements, local criteria levels, and a time frame for the completion of these objectives.

\section{Goal I: Collection Development and Evaluation}

- To develop and initiate a long-range plan for theevaluation of the quality and vitality of the library's book collection.

- Todevelop and initiate a long-rangeplan for the evaluation of the quality and vitality of the library's serials collection. 
- To develop and initiate a long-range plan for the evaluation of the quality and vitality of the library's curriculum collection.

- To develop and initiate a long-range plan for the evaluation of the quality and vitality of the library's U.S. government documents collection.

- To develop and initiate a long-range plan for the evaluation of the quality and vitality of the library's Pennsylvania collection.

- To develop and initiate a long-range plan for the evaluation of the quality and vitality of the library's pamphlet collection.

- To incorporate the aforementioned collection development procedures in the Acquisitions Policy Manual.

- To try, once again, to include more faculty in the collection development and evaluation process.

- To allocate funds for the organization and physical processing of archives and special collections.

\section{Goal II: Library Services}

- To establish a schedule for conducting library user and reference surveys, and performance studies.

- To suggest solutions for the problem areas highlighted by the library user survey, reference department survey, and performance studies; i.e., the library's hours, library noise and congestion, lack of awareness of certain library services by faculty and students (such as availability of typing rooms, telephone directories on $\mathrm{mi}$ crofiche, photocopiers, and audiovisual materials and equipment).

- To provide library orientation activities for new faculty; included in this objective should be the in-service training needs of faculty (old and new) in the use of automated retrieval systems.

- To develop and initiate a long-range plan for the evaluation of the quality and vitality of the library's reference collection.

\section{Goal III: Library Automation}

- To establish a standing advisory automation committee.
- To ask the aforementioned committee to develop a preventive maintenance plan for the library's computer hardware and software.

- To evaluate DIALOG services and CDROM indexes.

- To automate the serials circulation procedures.

\section{Goal IV: Staff Development}

- To develop a continuing program of systematic instruction and practice to aid in staff development.

- To encourage the improvement of library communication (in-house and campuswide).

- To request that all staff members participate in strategic planning at the departmental level.

\section{Goal V:Media Services}

- To develop and initiate a long-range plan for the evaluation of the library's audiovisual collection.

- To investigate further the library's media services. A good starting point might be the Media Services Subcommittee report requesting that the university look at the role of media services on campus.

\section{THE IMMEDIATE RESULTS}

From an administrative and managerial standpoint, the entire self-study process and its results have proven it one of the most worthwhile projects ever undertaken in the Manderino Library. We recognized the following points as immediate benefits:

1. Meaningful Strategic Planning. After such an in-depth analysis, we were certain of the strengths, weaknesses, and problems in our library system. As a result, strategic planning took on a new dimension, making the development of a fiveyear plan relevant and important to more of the library staff. Departmental and individual goals and objectives of the professional librarians have subsequently been tailored to act upon the SSC's final recommendations. For example, a newly formed automation advisory standing committee is already eval- 
uating our existing automated systems as they work on a five-year plan for Manderino Library's future automation. Everyone now thinks of future directions instead of only the current semester.

2. Improved Communication. Because so many people were involved, had input, and received constant updates, they automatically knew most of what was happening as it happened. The process had an inherent check-and-balance system, and no one felt threatened. The self-study process and the revised strategic plan are still actively representing how well people are communicating, both within the library and between the library and other university departments. The final report was distributed widely, thus becoming a good public relations tool as well as a source of information about the library and its programs. Internally, employees have a better understanding of the various jobs and duties of all staff members.

3. Orderly Collection Evaluation and Development. The entire process of evaluating and building the library's collection of both monographs and serials has been fine-tuned. A committee of library faculty, library staff, and teaching faculty members has implemented an effective means of addressing and eliminating deficiencies. Also, the committee will enhance the collection over the next three years, earmarking a part of the materials budget specifically for this project.

The committee is reviewing Books for College Libraries 3; recommending bibliographies, and outstanding books and serials lists by discipline; analyzing circulation and usage factors of materials presently owned by the library; and formulating the plan to address the outcomes of this process.

The collection evaluation project is being handled by individual colleges. The College of Science and
Technology completed the process in 1989-90, and the College of Education and Human Services is currently working on its portion.

4. Improved Budgetary Allocations. Having our reviews and plans documented in such detail has made it easier to justify to the university administration increases and shifts in the total library budget. Eighteen months of research, qualitative details, and quantitative data in widely read reports have made presentations to the university president and the cabinet more credible than usual. Our specific requests for money to support specific self-study recommendations are much easier to justify by referring to data than by simply claiming "the library needs more money." In 1990-91, we received a 10 percent increase in the library's budget allocation over 1989-90.

5. Useful Assessments of Library Resources. The Kania model and the self-study process forced us to conduct studies and surveys to analyze our performance, services, and interactions with clients. Some previous informal assessments about our effectiveness were certainly supported, and we now had clearer ideas about specific areas that would benefit from changes. For example, more than 90 percent of faculty and students who evaluated the reference librarians' services were more than satisfied with the quality and depth of the library's public services. Those surveyed also offered several suggestions for improvements.

6. Compliance with ALA Standards. As we followed Kania's model, and afterward, it was easy to determine whether or not our library complied with the 1986 Standards for College Libraries. We now had documentation to conduct an objective assessment of the application of performance and usage criteria that were so crucial to regional accreditation standards. The outcome 
of our assessments matched those of our consultants. Anyone who cared to review the data would find no hidden secrets, self-congratulatory conclusions, or misjudgments. Other university constituencies can easily understand how well we meet some of the standards' criteria and how we plan to achieve others.

7. Enhanced Atmosphere and Timing for Change. It is like spring cleaning and garage sales. After you have decided to do one, the other one follows, and before you can think about procrastinating, you have done both, and you feel better. The endless interviews, research, and examinations that are inseparable from self-study open the way for redesigns, changes, additions, deletions, and improvements. Individuals directly involved with these changes are already participating in the entire self-study process. Sometimes it is their idea to "go ahead and do this while we're at it." Or sometimes, the need for an additional employee changes from a perceived fantasy to an absolute reality; as supporting reasons accumulate, you wonder how you could have ever managed without this much-needed person.

For example, one of the major recommendations as a result of the selfstudy was to consolidate everything pertaining to serials within one department and hire a serials librarian. Our new serials librarian joined us six months after the self-study process ended. This change was natural; it was made as part of a total project and not done in isolation.

8. Total Staff Involvement. All twenty-eight members of the library staff participated in the selfstudy in some way or another. This is crucial in achieving positive outcomes. Everyone stated his or her opinions, and could complain and be heard. In many cases, individuals who had not previously interacted formally got a chance to do so, and we all benefited from the equality. This concept may sound a bit elementary, but it is a factor not to be overlooked in organizational group dynamics or library politics. It was important and rewarding in our case, especially in our relationship to organized labor.

What evolved into a policy of "communication without irritation" required attention to as well as honest, open acceptance of each person's contribution and each detail of each meeting. As a balance to this civility, within the groups people were encouraged to vent frustrations. Complaints usually began, "He's driving me crazy!" or "I can't stand the way she does this!" The group then provided suggestions to solve the day-today problems and restore harmony to the project.

The endless interviews, research, and examinations that are inseparable from self-study open the way for redesigns, changes, additions, deletions, and improvements.

In all cases, all such decisions were made openly and aboveboard. Most people learned quickly that everything would be handled fairly, no matter who was involved, and they gained confidence as they saw that all contributions had an equal chance, no matter who offered them. As a last resort, the decision moved up the chain of command to the dean, who acted from an administrative viewpoint.

The cooperation and outstanding efforts of the entire faculty and staff continue to be absolutely essential to our success. They took on the self-study process as part of, and in addition to, their respective job assignments with no release given, or expected. The entire study was accomplished with no reduction of library services.

\section{CONCLUSION}

The dean of library services and the chairman of the SSC (the authors of this article) have become firm believers in a 
process about which we were initially very skeptical. We thought it would take a great deal of work and a good deal of time, and it did. We were worried that all of our painstaking effort would be put on a shelf and never read. We were certainly wrong about that.

We were rewarded with unexpected praise and recognition. Beyond the list of benefits previously noted, we received a glowing evaluation, both written and verbal, from SSHE. The California University of Pennsylvania administrators praised our program and the value of the ongoing results to the university. Kania was very pleased to see how well our manifestation of her published model worked. We were asked to talk about our self-study program at an ACRL regional meeting, and after our presentations over half the audience requested copies of our final report. ${ }^{23}$

\section{A WORD TO THE SKEPTICAL}

Did the Manderino Library really do what is described in this article? Yes, it did, and overall it was a positive experience. Because a few colleagues who work at other libraries expressed doubts about the degree of our success, we have reexamined factors in our process to pinpoint why we neither failed nor achieved only mediocre success. We discovered several things: existing conditions at other institutions that would predestine failure and certain established conditions and practices at CUP that were (and are) pivotal to our success.

One colleague said, "This would never work at my library. We lack support from university administrators, including inadequate funds and staffing." Another complained that his school had weak library management, complemented by lazy employees. "I don't know how we would get them to do any of the self-study tasks. No one knows what's going on at the different job levels, and everyone's always suspicious of being given more work without more pay. It's us against them."

At CUP, credit must go to positive preexisting conditions, an excellent library administration, and communication. Our university is proud of our library; people throughout the system support us. Did we have problems? Yes, we did, and we dealt with them-immediately. Problems included passive/aggressive behavior, union worries, long-term illness and recovery, missed deadlines, and just plain dead ends.

We recognize that we were well prepared to take on the self-study process in ways that other libraries may not be. Because our employees are unionized, we had to get the most value from them in accordance with their defined job positions. By definition, we simply could not infringe upon their established job responsibilities. While our employees needed to feel comfortable, interested, and unstressed, all of them had an important role in the self-study process.

The self-study process and its results have proven it one of the most worthwhile projects ever undertaken in the Manderino Library.

We now realize how well the demands of our self-study process blended with the Manderino Library's established work environment. Life went on. The reference librarian still had to work a full schedule, while squeezing in frequent meetings of the Communications Committee and the SSC. As recording secretary of the SSC, she took detailed notes, and then quickly edited, wrote, and produced minutes that were immediately distributed to all library employees. In less than a day, everyone knew everything that had just been discussed. And throughout that day, questions that continued to pour into the reference desk were answered satisfactorily.

It is important to remember that university libraries differ greatly. Other institutions (especially those without unions) may be more unstructured, more spontaneous. Situations there may be handled as they occur, in a variety of ways, rather than in strict accordance with a collective bargaining agreement. Some administrators may rule more au- 
tocratically and be unfamiliar with the needs and concerns of their staff. If this is the case, we strongly recommend that this type of environment be modified before attempting our example of selfstudy process. We found that a "give and take" attitude among all participants and the same kind of management style were basic to our process.

Although "we" wrote this article, the spirit behind the "we" encompasses all of us at Manderino Library. We are still in it together. The self-study process was not a wasted academic exercise but the basis for a motivational document that has continued to produce growth and changes at Manderino Library. People quote from the report daily. "Why should we do this?" "This is a 'must'." "Oh ... right. No problem." No more need be said.

\section{REFERENCES AND NOTES}

1. State System of Higher Education, "Academic Policies," a policy statement from the chancellor's office of SSHE, 1989, p.[6-7] [actually unpaged].

2. Antoinette M. Kania, "Academic Library Standards and Performance Measures," College \& Research Libraries 49:16-23 (Jan. 1988). This is how one library adapted an outline to suit a necessary self-study program. It is an application, and this article is not intended as a critical evaluation of Kania's model.

3. Placing students on the steering committee was a good idea that unfortunately did not work out. Students were busy with classes and studying; it was difficult for them to attend meetings. Their participation was voluntary and brought no monetary reward.

4. Kania, "Academic Library Standards," p.22-23.

5. Ibid., p.22.

6. Ibid., p.23.

7. Kania writes: "The primary standards are those statements that utilize the verb must to indicate that the achievement of these standards ... . ought to be considered mandatory for academic library regional accreditation. . . . [Secondary standards] utilize either the verb should to indicate a professional obligation to achieve, or may to indicate that achievement is optional and, therefore, only advisable." Ibid., p.22.

8. Ibid.

9. Ibid.

10. Ibid.

11. Ibid.

12. Ibid.

13. Ibid.

14. Ibid., p.23.

15. Ibid., p.22.

16. Ibid., p.23.

17. Ibid., p.22.

18. Ibid., p.23.

19. Kania did not cite ongoing communication as a specific, individual activity. We added it to her outline under IV. Staff Standards. Ibid.

20. Kania, "Academic Library Standards," p.23.

21. Ibid.

22. Donald E. Riggs, Strategic Planning for Library Managers (Phoenix, Ariz.: Oryx, 1984), p.20.

23. Presentation occurred at the Delaware Valley Chapter ACRL fall program, Nov. 2, 1990 (Philadelphia). This sixty-one-page spiral-bound report, Marsha L. Nolf, "Louis L. Manderino Library Self-Study Final Report," May 19, 1989 (California, Pa.: California University of Pennsylvania), is available to readers free of charge. Send $\$ 4.00$ to cover photocopying and postage to Marsha L. Nolf, Manderino Library, California University of Pennsylvania, California, PA 15419. 